\title{
Domestic Judicial Defiance and the Authority of International Legal Regimes
}

\author{
Arthur Dyevre \\ KU Leuven \\ Faculty of Law \\ Tiensestraat 45 \\ 3000 Leuven \\ Belgium \\ arthur.dyevre@law.kuleuven.be
}

March 9, 2016

\begin{abstract}
Tensions and occasional overt defiance of international courts suggest that compliance with international regimes is not a self-evident choice for domestic judges. I develop a formal theory of domestic judicial defiance in which domestic and supranational judges vie for jurisprudential authority in a non-hierarchical setting. The model emphasises the role of domestic non-compliance costs and power asymmetries in determining the conduct of domestic and international judges. I argue that the EU represents a special case of a particularly effective international regime. Weak domestic courts have little to gain from an escalated conflict with the European Court of Justice. But even domestic judicial superpowers like the German Federal Constitutional Court have strong incentives to seek mutual accommodation with European judges. The analysis also yields new insights into concepts, such as "judicial dialogue" and "constitutional pluralism" that have featured prominently in the legal literature, and suggests new hypotheses for empirical research.
\end{abstract}

JEL Keywords: K40, C72, C73. 


\section{Introduction}

Compliance with international legal regimes commonly involves the judicial branch as well as the legislative and executive arms of the state. But just as other public officials, domestic judges may be tempted to resist the authority of international law. The problem is, to some degree, familiar to every multilevel governance structure. Even in a highly integrated federal polity such as the United States, state courts have sometimes overtly defied injunctions issued by the US Supreme Court (Sharkey, 2009). Yet this compliance problem appears to be magnified manifold when we turn to international regimes such as the EU or the Inter-American Convention on Human Rights, where no clear hierarchy exists between international and domestic tribunals. Unlike the US Supreme Court ${ }^{1}$ international courts, including the European Court of Justice and the European Court of Human Rights, lack the power to reverse the determinations of domestic courts.

For students of international regimes this fact suggests a number of puzzles. First, to a much larger degree than federal law in a federal system, the effectiveness of international law appears to hinge on the willingness of national judges to cooperate with their international counterparts. Yet the fear that international adjudicators might become rival lawmakers may induce domestic courts to resist cooperation. Instances of overt judicial defiance can be observed across a wide range of international regimes. The Supreme Court of Venezuela, for example, has refused to comply with orders issued by the Inter-American Court of Human Rights and has called on the Venezuelan government to withdraw from the Inter-American Convention on Human Rights. ${ }^{2}$ Similarly, in a noted 2008 decision, the US Supreme Court refused to enforce the International Court of Justice Avena judgement. Another illustration is the 2012 ruling of the Czech Constitutional Court which expressly pronounced the ECJ preliminary ruling in Landtová a ultra vires act (Bobek, 2014). What do these rulings tell us about the strength of these regimes? Do they constitute mere accidents bound, as such, to remain rare or are they symptomatic of a broader compliance problem? On the other hand, the

\footnotetext{
${ }^{1}$ The US Supreme Court was explicitly granted the authority to reverse state court decisions by Section 25 of the 1789 Judiciary Act. A prerogative the Court first put to use against Virginian courts in Fairfax's Devisee v. Hunter's Lessee, 11 U.S. 603 (1813)(Story,J.).

${ }^{2}$ Tribunal Supremo de Justicia, Decision No. 1939 of 18 Dec. 2008, Gustavo Álvarez et $a l$. .
} 
absence of hierarchy between international and domestic courts may open the possibility for domestic judges to negotiate the terms of the compliance partnership. One way for domestic judges to back their bargaining position is to issue non-compliance threats. In the EU such threats have become increasingly frequent over the years. On several occasions, the German Federal Constitutional Court (GFCC) has warned the ECJ that EU acts found to go beyond the EU's remit would be ruled unconstitutional (Stein, 2011, Alter, 2001). The German ultra vires doctrine was then embraced by several courts in other EU member countries and inspired the 2012 Czech constitutional ruling (Sadurski, 2008, Bobek, 2014). How effective are such threats? How do disparities in institutional stature bear on the ability of domestic courts to extract concessions from international judges? A further puzzle arises from the situation where neither overt defiance nor non-compliance threats are observed. Can it be attributed to the effectiveness of the international regime? Or does it result, on the contrary, from international judges exercising restraint out of fear that national courts might disbobey their rulings?

The present paper seeks to elucidate these puzzles by developing a formal model of inter-court interaction in non-hierarchical settings. The model has an international court and a domestic high court competing over jurisdictional resources. The two courts, however, incur institutional costs when a jurisdictional dispute escalate into an all-out constitutional crisis. For international judges, these crisis costs represent the loss of authority that directly results from domestic non-compliance. For domestic judges, they represent the institutional price of defiance when refusal to comply with international rules triggers an adverse domestic reaction, as legislators proceed to punish the rebellious court for undermining their country's commitment to the international regime. The baseline model shows that variations in crisis costs lead to distinct outcomes which reflect the depth and effectiveness of the corresponding international regime. Other things being equal, higher crisis costs for domestic judges are associated with greater effectiveness. Even within effective international regimes, though, the fate of domestic judges may vary significantly. Power asymmetry entails that weak domestic courts have much to lose and little to win from an escalated conflict with a powerful international court. Domestic judicial superpowers, meanwhile, are in better position to contain activist international judges, although power symmetry means they have strong incentives to seek mutual accommodation and to avoid escalation. I then consider extensions to the baseline model that help bring the use of non-compliance threats by domestic high courts in strong 
international regimes into sharper focus. Non-compliance threats are modelled as cheap talk, which domestic judges can use to communicate their preferences over the jurisdictional issue at stake. I demonstrate that, under certain conditions, the non-compliance threats issued by a powerful domestic court can function as an effective signalling device as part of a peaceful issue-trading equilibrium. Without being actually carried to execution, such threats can be viewed as an effective instrument of judicial dialogue. I discuss ECJ-GFCC relations in the EU in light of this finding. I also discuss the situation of high courts in other member states that have imported the GFCC's ultra vires doctrine into their own jurisprudence and issued similar non-compliance threats. I argue that because these courts lack the GFCC's deterrence capability they are unable to extract large jurisdictional concessions from the ECJ. For the same reason, even in the rare occasions where these weaker judicial actors have followed through on their threats this behaviour may be more accurately interpreted as an accidental departure from an ECJ supremacy equilibrium than as evidence of a systemic compliance problem. This result highlights the limits of doctrinal borrowing when courts seek to emulate the jurisprudential strategies of judicial bodies operating in more favourable institutional environments.

The paper is organized as follows. Section 2 briefly reviews the literature on domestic judicial compliance. Section 3 presents the baseline model, discussing its key assumptions, equilibria and comparative statics. When both courts prefer a jurisdictional loss over a constitutional crisis, I show that the interaction follows the logic of a Hawk-Dove game. I relate this game form and the corresponding equilibrium solutions to the discussion over "constitutional pluralism" in the EU law literature. Situations of power asymmetry are shown to result in a supremacy equilibrium either of international law or of domestic law, depending on which court has the upper hand. When both courts prefer a constitutional crisis over a jurisdictional loss, on the other hand, a contentious equilibrium result in which the two courts disregard each other's pronouncements. Section 4 refines this essentially static analysis by making interactions between the two courts more dynamic. I introduce several extensions to the baseline model. These include repetition, imperfect information and communication. Section 5 uses this revised model to derive an issue-trading equilibrium in which domestic and supranational judges accommodate each other on the basis of the importance they attach to the issue at hand. In this "pacific coexistence" equilibrium, domestic judicial signalling serves to disclose the domestic court's preferences, which in 
turn enables the two courts to coordinate their moves. I use this equilibrium to explain how ECJ-GFCC relations have evolved over time. Section 6 then considers the situation of weaker domestic courts in deep international regimes and the limits of doctrinal borrowing. I conclude by considering some implications of the analysis for future research on domestic judicial compliance.

\section{Legal and Social Science Research on Do- mestic Judicial Compliance}

Scholars from various disciplines and theoretical traditions have stressed embededness, the penetration of domestic legal orders, inter-judicial dialogue and compliance partnerships between domestic and international judges as a

key determinant of state compliance with international law (Keohane et al. 2000, Downs et al., 1996, Huneeus, 2011). Domestic courts are viewed as essential not only to first-order compliance with treaty obligations but also to second-order compliance with the decisions of supranational judicial bodies. Despite a surge of interest in international dispute resolution and international tribunals in recent years, however, research on the dynamics of domestic judicial compliance is still in its infancy (Huneeus, 2013).

Within political science, students of law and courts have tended to emphasise the cooperative aspects of the interplay between international and domestic judicial power. An important line of inquiry has focused on the willingness of national courts in the EU to submit references to the ECJ via the preliminary ruling mechanism (Stone Sweet and Brunell, 1998, Carrubba and Murrah, 2005, Golub, 1996). A notable exception to the general focus on preliminary references in this literature is Alter $(2001)$. Looking at France and Germany, her analysis carefully charts patterns of juridical resistance as well as cooperation in the gradual-albeit far from linear-process that eventually established EU law as supreme. Her institutionalist narrative of legal integration suggests that, in the EU legal order, legal doctrines represent the currency of inter-judicial negotiation. Alter has also argued that domestic apex courts are more likely to resist integration as it threatens to disrupt their authority over the lower echelon of the court system (Alter, 1998). In subsequent work, she has set out to explain why international judicial bodies designed along similar lines have failed to establish the close rapport with 
domestic courts achieved by the ECJ (Alter and Helfer, 2010, Alter, 2012). Even so, this research does not identify the bargaining strategies deployed by the interacting judicial actors. Nor does it specify the conditions under which non-compliance threats may achieve to contain the expansionist impulses of an otherwise powerful international court without calling into question the regime's very existence in the process.

Unlike political scientists, legal scholars have grappled in equal measure with the cooperative and the conflictual dimension of the reception of international law by domestic courts. Law scholars see wide disparities in the attitude of domestic judges towards international rules and norms (Nollkaemper, 2013). Echoing Karen Alter's court competition hypothesis, they have also pointed to the reluctance of certain constitutional courts to embrace cooperation with international tribunals (Huneeus, 2011, Kumm, 2006, Dyevre, 2013). Furthermore, EU law scholars acknowledge the strategic nature of inter-court interactions in the EU legal order (Weiler and Haltern, 1996). This is especially apparent in the two narratives that have come to dominate the EU law literature, namely "judicial dialogue" and "constitutional pluralism". Devised to capture the complex interplay between the European Court and its domestic judicial interlocutors, these two narratives stress "mutual recognition", "interaction" and "negotiation" as central to judicial decision making in a non-hierarchical legal system (McCormick, 1999, Poiares Maduro, 2003, 117-8). Scholars of European law claim to place these notions at the centre of their picture of law. Yet, because legal scholars, particularly on the Continent, tend to approach these issues through the exclusive lens of doctrinal analysis, the paradox is that they have relatively little to say about them.

That the stakes are large for the actors involved along with the fact that they typically interact in repeated fashion makes strategic, utility-maximizing behaviour more likely ${ }^{3}$, suggesting that the question is one eminently suited for formal modelling. Yet no existing model of judicial politics really addresses the situation of courts in non-hierarchical settings. To be sure, interjudicial relations form the focus of a rapidly expanding body of research (Westerland et al., 2010, Cameron et al., 2000, Lax, 2003, Kastellec, 2007). Yet the researchers who developed these formal models did so with the US

\footnotetext{
${ }^{3}$ Experiments show that play is more likely to converge towards strategic Nashprescribed equilibrium when players have already taken the game several times (Nagel 1995)
} 
judiciary in mind. Accordingly, their models presume that the interacting courts stand in a hierarchical relationship to one another. Judicial compliance is thus essentially approached as a principal-agent problem, as higher court judges seek to maximise lower court compliance through optimal use of their limited monitoring capacities. These models, however, do not adequately capture the very distinct bargaining conditions under which courts operating in non-hierarchical settings operate.

A careful perusal of the literature reveals that formal modellers have not entirely ignored international legal regimes and we can point to Carrubba (2005) and Garrett et al. (1998) as valuable attempts to model EU judicial politics. The assumptions of these two models, though, are at odd with the emerging interdisciplinary consensus on the bases of domestic compliance. Indeed, premised on an inter-governmentalist approach to European integration, they assume that member state governments are the sole interlocutors and source of external constraints for the ECJ. In other words, they appear to overlook the relationship the European Court has developed with domestic judges, which various strands of literature have identified as crucial to the legal integration process.

\section{Judicial Conflict in a Non-Hierarchical Set- ting: Jurisdictional Interests and Non-Compliance Costs}

The baseline model set out in the present section is consistent with recent judicial behaviour research on both international and domestic courts Epstein et al., 2013, Pollack, 2013). The model assumes that domestic courts represent a key determinant of the depth and authority of international legal regimes (Keohane et al., 2000, Huneeus, 2011). I also assume that inter-court dynamics are influenced by the position of domestic governmental actors, including legislators (Dyevre, 2010). Rather than with the domestic judiciary as a whole, my analysis is primarily concerned with the behaviour of high court judges. There are two reasons for this focus on high courts. The first is institutional. High courts make decisions that are more impactful, as they typically enunciate the doctrines that are meant to guide the conduct of lower domestic courts. The other is that lower court judges face a distinct set of incentives and constraints when it comes to the application of 
international norms (Alter, 1998, Huneeus, 2011). These differences call for a distinct modelling approach. For related reasons, I focus on overt, rather than covert, domestic judicial defiance. Judicial deviations from international rules may take subtle forms such as distinguishing. Domestic courts may also knowingly deviate from an international norm without even mentioning the existence of the latter in their rulings. Yet covert non-compliance cannot, by definition, convey a clear message to the courts' domestic and international audiences. So, unlike overt defiance, covert defiance is unlikely to have systemic consequences. $\left.\right|^{4}$

\subsection{Baseline Game}

Disputes between international and domestic high courts present three salient characteristics. First, such disputes are fundamentally about jurisdiction. Here I employ "jurisdiction" in the capacious sense of "authority", "power" or "influence" rather than in the narrow, technical sense of "formal right to review a case". Tensions between domestic and international courts arise because of disagreement over who should decide-whether it is about standards of human rights protection, labour regulations, trade or the limits of the powers delegated to international law-makers. Generally speaking, given that one court's jurisdictional gain is the other's loss, judges on the opposite ends of a jurisdictional dispute have antagonistic institutional interests. The courts involved are thus bound to view jurisdiction as a rivalry good. To be sure, domestic and international judges may sometimes see eye to eye. A weak domestic court may embrace international law as a strategy to bolster its legitimacy at home. Compliance partnerships between international and domestic courts may thus be mutually beneficial as judicial actors seek to expand their overall influence against the executive and legislative branch. The point, though, is that such circumstances are unlikely to give rise to a jurisdictional dispute 5 Second, inter-court disputes are about institutional

\footnotetext{
${ }^{4}$ Since covert non-compliance is less costly for the international regime and, for the same reason, less likely to trigger court curbing at domestic level, we might speculate that it is more prevalent in advanced regimes. However, I leave it to future research to identify when domestic judges will opt for covert rather than overt defiance.

${ }^{5} \mathrm{~A}$ more comprehensive model of national-international court interaction would also consider the conditions under which judges sharing the same agenda will want to cooperate. This question, however, lies outside the scope of the present paper, which focuses on judicial defiance-that is, on situations where domestic and international judges pursue
} 
standing. Because international judges lack the power to overturn the decisions of national courts, an overt dispute between national and international courts automatically turn into one about the authority of the international regime and that of its court. Even in the EU, a high court disagreeing with the ECJ retains the formal power to refuse compliance. ${ }^{6}$ Institutional standing matters for international courts because a domestic ruling overtly defying their commands makes disobedience more likely in the future. Finally, disputes pitting international courts against domestic judges are about commitment. A domestic court refusing to comply with the pronouncements of an international tribunal tests its country's commitment to the international regime in question. If the executive and legislative branches-or the public at large-are strongly committed to the regime, the defiant court risk being viewed as harming the country's interests and international reputation. This, in turn, may expose it to institutional reprisals in the form of legislative override, jurisdiction-stripping, etc. Conversely, when this commitment is weak, domestic judges may defy the authority of international law without fear of legislative pushbacks.

Represented in Figure 1 is the payoff matrix of a simple game that attempts to capture these factors. The two players, the International Court and the Domestic Court, compete over a jurisdictional resource and the two courts must decide whether to be assertive or to exert restraint. If both courts exert restraint, they end up sharing the jurisdictional resource. If one court is assertive and the other acquiesces (by exerting restraint), the assertive court accrues the full value of the jurisdictional resource, while the acquiescing court incurs a loss. Finally, when both courts play assertive, a constitutional crisis ensues. As a result, the two courts must not only share the jurisdictional resource at issue, but also bear the costs arising from the crisis.

\section{Figure 1 about here}

As for the judges' utility function, $J$ and $\alpha$ in Figure 1 denote the value attached to the jurisdictional resource by, respectively, the Domestic Court and the International Court $(J>0$ and $\alpha>0)$. $\beta$ represents the institutional cost suffered by the International Court in the event of a constitutional

antagonistic interests.

${ }^{6}$ Surely, some international legal regimes, such as the EU and the Andean Community, allow international judges to intervene directly in domestic disputes via interlocutory procedures. Yet such procedures, like the preliminary ruling mechanism in the EU, can only be activated at the behest of domestic judges. 
crisis $(\beta>0)$. Its magnitude reflects the institutional damage that domestic judicial defiance inflicts on the authority of international judges. Meanwhile, $C$ captures the institutional cost incurred by the Domestic Court when the dispute results in a constitutional crisis $(C \geq 0)$. $C$ can be interpreted as reflecting the commitment of governmental actors to the international regime and their willingness to punish judges who renege on that commitment 7 $C=0$ can be interpreted as the absence of commitment to the international regime or as the incapacity of governmental actors to curb the defiant court, owing e.g. to high political fragmentation or to strong public support for the judicial branch. Alternatively, it can be interpreted as unwillingness to embed the international regime. Reflecting a dualist stance on the relationship between domestic and international law, legislators and other governmental actors are satisfied to keep it a strictly inter-state agreement. By contrast, $C>0$ indicates that the governing coalition has some commitment to the international agreement, at both domestic and international level, and that they are effectively in position to curb judicial defiance 8 While explaining judicial behaviour in general may arguably require a more elaborate utility function (see Epstein et al., 2013, 48), this simple model seems to adequately capture the decisive factor on which jurisdictional disputes habitually turnnamely the value judges attach to power and prestige.

Various equilibria can be derived from this game using dominance, best response and Nash solutions. These equilibria reflect the value of the arguments in the judges' utility function-i.e. how judges weigh institutional costs and benefits-and the way in which they anticipate each other's behaviour. Displayed in Tabled 1 are the four main outcomes generated by the model as a function of its parameter values. As their names suggest, these four outcomes correspond to international regimes enjoying disparate levels of depth

\footnotetext{
${ }^{7}$ A large $C$ value may also reflect a low degree of judicial independence. This captures the basic notion that courts lacking institutional autonomy have incentives to kowtow to the preferences of the other branches.

${ }^{8}$ Possible extensions to this basic model would consider the possibility for judicial agendas to converge (with the possibility that $J<0$ ) along with the possibility for legislators to punish the Domestic Court for upholding, rather than for flouting, international law. (In many countries, legislative opposition to international law rather than judicial resistance may be the principal obstacle to the domestic application of international legal rules.) Also, whereas I presume the legislative reaction to be exogenous to the courts' behaviour, there may be scenarios where conceptualising legislative behaviour as endogenous to judicial decision making might make more sense. But I leave these extensions for future research.
} 


\section{International Court}

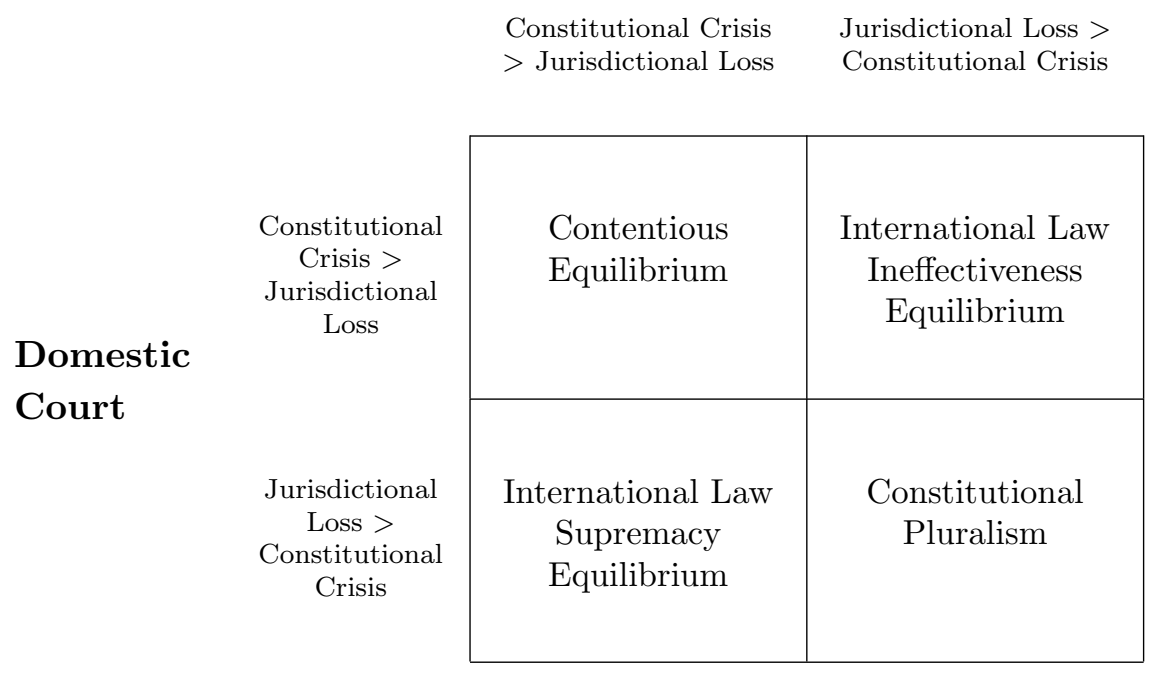

Table 1: Comparative Statics, Baseline Model.

and integration. I consider each outcome in turn.

\subsection{International Law Ineffectiveness Equilibrium}

An international legal regime is at its weakest when international judges prefer acquiescence over a constitutional crisis but domestic judges, due to low crisis cost and strong jurisdictional interest, prefer an escalated conflict over a jurisdictional loss. This asymmetry yields an equilibrium in which assertiveness is a dominant strategy for the Domestic Court while the International Court's best response is to acquiesce $9^{9}$ Low commitment across constituent

\footnotetext{
${ }^{9}$ Because best response, unlike dominance, presupposes complete information as well as common knowledge of rationality, it is also behaviourally less robust (see Costa-Gomes et al. 2001). Empirically speaking, we are thus more likely to observe unilateral departures from the equilibrium outcome in the case of international judges. As the fate of the Southern African Development Community (SADC) Tribunal illustrates, though, a weak international court that misjudges the preferences of domestic courts does so at its own peril. In the first salient case it was given to review, the SADC Tribunal ruled that Zimbabwe's farm eviction amendment amounted to de facto discrimination of white farmers. Yet not only did the High Court of Zimbabwe refuse to enforce the judgement but member
} 
member states means that many existing international regimes, including the Economic Community of West African States (ECOWAS), the Organisation for the Harmonisation of Business Law in Africa (OHADA) and the Andean Community, may fit this configuration (Alter and Helfer, 2010, Alter, 2012). Ineffectiveness also appears to characterize the context in which the ECJ found itself in its early years (Alter, 2012, 151).

Paradoxically, weak regimes are likely to see few overt jurisdictional disputes as international adjudicators, anticipating non-compliance, restrictively interpret the provisions enshrined in the international agreement (Alter and Helfer, 2010). Even in its landmark Costa v. ENEL ruling, the ECJ was careful to avoid a clash with the Italian Constitutional Court and held that EU law was not directly applicable to the Italian legislation at hand (Alter, 2001, 19). Frequently, though, weakness means that international agreements and the rulings of international tribunals will barely register with domestic judicial actors (Nollkaemper, 2013). In such circumstances, the rarity of defiance masks, in reality, the regime's shallow depth (Downs et al., 1996).

This analysis implies that what appears to be relatively widespread cooperation with domestic courts may lead scholars to exaggerate the strength of an international regime. Especially when domestic courts were initially weak, the prospect of acquiring new powers at the expense of governmental actors may induce them to cooperate with international adjudicators. Yet interest alignment can only sustain cooperation up to the point where it ceases to be advantageous for domestic judges. Thus, even in regimes where domestic and international judges share the same interests across a broad range of issues, compliance risks breaking down as soon as conflicts arise.

\subsection{Contentious Equilibrium}

When both courts prefer a constitutional crisis over a jurisdictional loss, this results in a contentious equilibrium, in which assertiveness is the dominant strategy for both judicial actors 10 This equilibrium may reflect national disparities in regime commitment. An international legal regime may thus enjoy sufficient support across a sufficient number of constituent member states to withstand non-compliance in a single state ${ }^{11}$ Given the Chavez-

state governments subsequently proceeded to disband the Tribunal.

${ }^{10} \mathrm{As}$ long as $3 J>C>0$, the game is a Prisoner's Dilemma.

${ }^{11}$ Defiance in one member state, though, may have a domino-effect in other member countries as each defection makes commitment to the regime less valuable until the tip- 
led government's low support for the Inter-American Convention on Human Rights, the Supreme Court of Venezuela could safely ignore the order issued by the Inter-American Court. Yet the latter enjoyed sufficient support in other member countries so that defiance by Venezuelan courts did not pose a systemic threat to its authority. Similarly, in Medellin v. Texas the US Supreme Court was unlikely to face any pressure from Congress to comply with the International Court of Justice ruling. But, because support for its existence is spread across many member countries, the ICJ was nonetheless able to survive US defiance almost intact.

In some cases, reciprocal disregard may reflect the purely inter-state nature of the international legal regime. States are willing to meet the requirements of an adverse international rulings but only to the extent that it does not affect the operations of the domestic legal order. Thus states may agree to pay a compensation to the aggrieved party but not to force their judges to apply international law. The upshot is a dualist conception of the relationship between international and domestic law, which does not threaten the existence of international judges but prevents their policy determinations from penetrating domestic law. To deny the regime direct effect, domestic judges typically invoke non-self-executing treaty doctrines, which tend to be relatively indeterminate and, as such, susceptible to strategic manipulation (Nollkaemper, 2014) ${ }^{12}$ A prime example of legal dualism along these lines is provided by the treatment of World Trade Organisation law in the US legal system. WTO panels and the Appellate Body have issued numerous rulings against the United States. Yet both Congress and US courts have consistently refused to give direct effect to WTO rules (Grimmett, 2011).

Still other regimes may have transited through this equilibrium until rising non-compliance costs worked to make resistance unaffordable for domestic judges. This may approximate the situation in which the EU found itself between the early 1970s and the early 1980s. At this intermediate stage of integration, the ECJ had managed to enlist the support of some domestic judges and several landmark rulings that had direct bearing on national economic policy-making came down during this period. Yet supremacy and direct effect were still a contested component of EU membership. French

ping point where the regime begins to collapse. I leave it to future work to explore how interactions among courts in different member states may affect compliance dynamics.

${ }^{12}$ These doctrines illustrate the general assumption underlying the present analysis that legal reasoning rarely constitutes a real constraint on judicial decision making in cases pertaining to the relationship between international and domestic law. 
legislators, in particular, opposed the notion that EU law ought to have priority over domestic legislation. So when the French supreme administrative court, the Conseil d'Etat, overtly defied the authority of the Luxembourg judges with its 1978 Cohn-Bendit ruling, 13, it was unlikely to face legislative reprisals (Alter, 2001).

\subsection{Weak Domestic Courts, Strong International Judges: International Law Supremacy Equilibrium}

The Domestic Court is weakest and the International Court strongest when domestic judges prefer acquiescence over a constitutional crisis but international judges prefer a constitutional crisis over a jurisdictional loss. In this configuration, assertiveness is a dominant strategy for the International Court while restraint is the Domestic Court's best response. Such parameter values appear to approximate the relations between the ECJ and most domestic high courts in the EU as it exists today. Despite the rise of Euroscepticism and Eurosceptic protest parties, virtually all government parties in the member states remain officially committed to EU membership (Szczerbiak and Taggart, 2008, Taggart and Szczerbiak, 2008). Moreover, supremacy and direct effect are now viewed as an integral part of EU membership.

By signalling greater political commitment to EU law, the relaunch of the European project under Franco-German leadership in the 1980s created the conditions for further integration of the EU legal order. By raising the domestic cost of defiance, the shift allowed the ECJ to become an expansionist supranational lawmaker without triggering widespread judicial rebellion in the member states. A clear sign that the tide had turned in favour of the European Court was the new attitude of the French Conseil d'Etat which reversed its long-standing opposition to EU law supremacy in 1989 (Alter, 2001).

These conditions have helped turn the EU into what is arguably the most effective international legal regime. They also suggest that the only instance of overt non-compliance of the last three decades, the aforementioned decision of the Czech Constitutional Court, is best viewed as one-off, accidental departure from the long-term equilibrium outcome. The Czech decision appears to have been mainly driven by domestic judicial politics-a long-standing spat between the Constitutional Court and the Supreme Administrative Court

\footnotetext{
${ }^{13} 22$ December 1978, Ministre de l'intérieur v. Cohn-Bendit, Rec. 524.
} 
over pension rights (Bobek, 2014). But the Czech constitutional judges may also have misjudged the domestic environment, hoping their decision would rally legislative and presidential support. At any rate, the upshot was that the Czech Constitutional Court was left diminished and isolated, while the ECJ's authority emerged largely unscathed from the episode (Bobek, 2014).

\subsection{Judicial Superpowers: Inter-Court Disputes as Hawk- Dove Game}

When the parameter values are such that both courts prefer acquiescence over a constitutional crisis, the jurisdictional dispute exhibits the structure of a Hawk-Dove Game ${ }^{14}$ The Hawk-Dove set-up provides a good first approximation of patterns of interaction between the ECJ and the GFCC in the EU. Of all member state courts, the GFCC is the one with the strongest credentials to judicial superpower status. Not only is Germany a founding Member State and Europe's largest economy. But the GFCC also enjoys unrivalled institutional standing at home. Thanks to wide access rules and far-reaching docket control, it has a much tighter grip over its agenda than any other constitutional court in the EU. For all these reasons and because its jurisprudential pronouncements attract more media coverage both at home and abroad, the GFCC has greater capacity to inflict damage on the ECJ. A ultra vires ruling by the German Court would be more likely to trigger a domino-effect than the same decision by any other Member State court. At the same time, though, such a ruling would not only greatly endanger the authority of EU law but would also undercut the credibility of Germany's commitment to integration. This, in turn, would expose the GFCC to a legislative backlash back home.

This Hawk-Dove approximation points to the strategic tension that lies at the heart of the EU legal order. Players in a one-shot Hawk-Dove Game have no dominant strategy. Instead, the game has two pure strategy Nash equilibria. This stems from the fact that one court's best response to the other court's assertiveness is to exert restraint, but its best response to a restrainist court is to be assertive. Evidently, each court prefers the equilibrium in which it is the hawk (thereby accruing the full value of the jurisdictional resource) and the other court acts as the dove. The environment thus is

\footnotetext{
${ }^{14}$ The Hawk-Dove Game is also known as the Game of Chicken, and less famously as the Snowdrift Game.
} 
one in which both courts have an incentive to pursue a policy of judicial brinkmanship. Each court would like to intimidate the other into playing restraint so that it can safely play assertive and reap the full jurisdictional gain. Given that the two courts have the same incentive, though, choosing the assertive strategy runs the risk of triggering a constitutional crisis-the worst possible outcome for the two players.

To limit the chance that they wind up in an equilibrium in which they have to acquiesce to the other court's assertiveness while reducing the probability that the dispute escalates into a full-scale constitutional crisis, the two courts may want to randomize among the pure strategies. In particular, each may want to play the assertive strategy not with probability $p=1$ but with a probability sufficiently high to discourage the other court from opting for a pure assertive strategy. A pair of mixed strategy profiles constitutes a Nash equilibrium if each player associates the same expected utility with each of his pure strategies. In other words, in a mixed strategy Nash equilibrium, the players randomize so as to balance out the risks and benefits associated with each pure strategy. The probability assigned to a particular strategy must thus reflect the relative value of the associated payoffs. One implication for our Hawk-Dove setup is that when the net cost arising from a constitutional crisis is not much greater than the jurisdictional loss associated with acquiescence, the courts will want to play the assertive strategy with a higher probability. But when this cost is much larger than the loss attached to acquiescence the courts will play the assertive strategy with a much lower probability. A corollary is that, as shown in Figure 2, the probability of a jurisdictional dispute actually escalating into a constitutional crisis decreases sharply, to approach zero, as the cost associated with such an event goes up. ${ }^{15}$ For large crisis costs, we are more likely to observe the courts peacefully sharing the jurisdictional resource than an escalation into an all-out judicial war.

\section{Figure 2 about here}

Legal scholars have noted the parallel between Cold War international relations and the ECJ's relationship with the GFCC. Weiler and Haltern (1996, 446-7), for example, argue that the GFCC has power to inflict massive damage on the European Court, but the sheer scale of the repercussions

\footnotetext{
${ }^{15}$ The analysis here is predicated on the interpretation of mixed-strategy equilibria as equilibria in actions. An alternative, and arguably more realistic, interpretation is to see mixed-strategy equilibria as equilibria in beliefs (Aumann and Brandenburger, 1995).
} 
it would have for the EU, for Germany, and for the German Court itself, makes an escalated judicial conflict between the two institutions an unlikely prospect. Their analysis suggests that what holds together the EU legal order is something akin to the Cold War doctrine of Mutual Assured Destruction (famously acronymed as MAD). The Cold War analogy, in turn, suggests a neat way of re-interpreting the notion of constitutional pluralism-central to EU law scholarship-in terms that are more explicitly empirical. As with MAD, constitutional pluralism thus characterizes a particular equilibrium where courts must be attentive to each other's interests, lest they face a mutually baneful crisis.

\section{Extensions: Iteration, Communication and Incomplete Information}

The parsimonious model expounded above helps cast light on some of the mechanisms that modulate relations between domestic and international adjudicators. The literature on international courts emphasises the importance of institutional design-notably formal access rules-as key determinant of their influence (Keohane et al., 2000). Yet design can only account for a fraction of the observed variation. And so, one merit of the baseline model is to help elucidate why institutional design does not always predict effectiveness. It has been argued that many international judicial bodies modelled after the ECJ "resemble more closely in practice the ECJ during the 1950s and 1960s than the ECJ today" (Alter, 2012, 151). Regarding the ECJ, a related merit of the model is to show how the EU is (and has become) unique, rather than assumes its uniqueness or sui generis character. Still, there are important elements of the dynamic nature of judicial interactions in advanced regimes like the European Union that the model fails to capture. First, judicial superpowers like the ECJ and the GFCC do not interact in simultaneous, one-off manner but in sequential, repeated fashion. When played sequentially instead of simultaneously, the Hawk-Dove Game confers a clear advantage on the first mover. If, for example, the International Court moves first and chooses to be assertive, the Domestic Court must then choose between a jurisdictional loss and a constitutional crisis. Since acquiescence is the Domestic Court's best response in this situation, the model, thus modified, would predict that activist international judges will always have the 
upper-hand, at least as long as they move first. The unpalatable prospect of facing such a dilemma can spur real-world players to look for ways to lower the cost of a confrontation so as to escape the implacable logic of the sequential Hawk-Dove game. So, in the same manner that this realization spurred the Kennedy administration to abandon massive retaliation in favour of flexible response as US defence strategy, a domestic court like the GFCC may want to lower the costs associated with a constitutional crisis, both for itself and the ECJ. A suggestion in that sense was made by the Court's former President, Roman Herzog, in a feature article that appeared in the Frankfurter Allgemeine Zeitung in September 2008. Herzog urged the GFCC "to stop the ECJ" and to punish it for its recent bout of activism. Herzog suggested that German constitutional judges declare the ECJ ruling in the Mangold case ultra vires. As Herzog pointed out, the holding in Mangold was, by the time, already moot, superseded as it had been by the entry into force of a new directive. Therefore, the GFCC would not put the authority of EU law immediately at risk by pronouncing it a ultra vires act. The reasoning was explicitly that Mangold provided the GFCC with a less destructive means to show resolve (Herzog, 2008).

Repetition, however, can neutralize this first-mover advantage. By enabling human agents to punish or reward past behaviour, repetition and the prospect of continued interplay fundamentally change the nature of social interactions. In particular, the prospect of punishment (or reward) in subsequent encounters may suffice to give the agents an incentive to cooperate in the present (Kümmerli et al., 2007, Axelrod, 1984). Judges in the EU, too, have memory of past interactions and are aware that they may interact again in the future. As inter-court interactions take place against such indefinite horizon, equilibria that would not be sustainable in a one-shot game may thus become viable.

Another characteristic of advanced international regimes like the EU is that they involve regular communication between international and domestic judges. Much of what legal scholars call "judicial dialogue" occurs in the form of obiter dicta, whereby courts signal their position on a particular issue without making any concrete, final determination (Arnull, 2012). National courts in the EU have often used such dicta to convey threats to disapply EU law should EU institutions overstep their mandate or breach some constitutional red line. Moreover, these threats are issued in a context of incomplete information. Just as ECJ judges are unlikely to have perfect information about the preferences of domestic judges, so too are domestic 
judges likely to possess complete knowledge of the policy preferences of ECJ judges. Incomplete information, in turn, creates an incentive for judges to appear more hawkish than they really are in the hope of persuading the court on the other side of the dispute to yield to their demands. This directly relates to the doubts raised by legal scholars as to the effectiveness of domestic non-compliance threats when these are never carried to execution (Weiler, 2009, Schmid, 2001).

The model I set out in the present Section incorporates these extensions. Figure 3 illustrates the stage game. The game starts with the International Court expanding the remit of the international regime. The Domestic Court must then decide whether to respond by issuing a non-compliance threat $(T)$ or not $(\sim T)$. The next move is for the International Court to choose whether to maintain $(M)$ or to reverse $(\sim M)$ its initial activist stance ${ }^{16}$ If it chooses $\sim M$, the Domestic Court wins the jurisdictional dispute and reasserts its authority. But in case the International Court holds firm to its expansionary jurisprudence, the last move rests with the Domestic Court, which chooses whether to respond by disapplying the International Court ruling $(D)$ or not $(\sim D){ }^{17}$ If, playing $\sim D$, the Domestic Court acquiesces, then the Domestic Court loses the jurisdictional dispute and the International Court accrues the full value it attaches to the jurisdictional resource. Finally, when the Domestic Court chooses to defy the International Court by playing $D$, a constitutional crisis ensues ${ }^{18}$ Whenever the end of a branch of the game

\footnotetext{
${ }^{16}$ This sequence is consonant with accounts of the decision making practices of activist international courts by legal scholars. Trevor Hartley, for example, observed that the ECJ frequently follows a test the waters tactic to develop its case law:
}

A common tactic is to introduce a doctrine gradually: in the first case that comes before it, the Court will establish the doctrine as a general principle but suggest that it is subject to various qualifications; the Court may even find some reason why it should not be applied to the particular facts of the case. The principle, however, is now established. If there are not too many protests, it will be re-affirmed in later cases; the qualifications then can be whittled away and the full extent of the doctrine revealed (Hartley, 1988. 78-9).

\footnotetext{
${ }^{17}$ Note, though, that the act disapplied does not have to be a judgement issued by the International Court but may be another rule emanating from the same international regime (e.g. a decision enacted by the European Central Bank or the Commission in the case of the EU).

${ }^{18}$ For illustrations of what these moves may concretely amount to I refer to the examples provided in the introduction and the discussion in Section 5 .
} 
tree is reached, the courts accrue the corresponding payoffs and the game repeats. The model consists of the infinite repetition of this stage game.

Figure 3 about here

As before, the courts care about both jurisdictional authority and potential crisis costs (when the Domestic Court decides to defy the activist International Court), but with one major difference. A court may be of two types: type $\in\{h a w k$, dove $\}$. The hawk type associates jurisdictional expansion or reassertion with a higher gain $\left(J^{h}\right.$ for the Domestic Court and $\alpha^{h}$ for the International Court) but also acquiescence with a higher loss (respectively $-J^{h}$ and $\left.-\alpha^{h}\right)$. The doveish type, on the other hand, associates assertiveness with a smaller gain (respectively $J^{l}$ and $\alpha^{l}$ ) but also acquiescence with a smaller loss $\left(-J^{l}\right.$, with $-J^{h}<-J^{l}<0$ for the Domestic Court, and $-\alpha^{l}$, with $-\alpha^{h}<-\alpha^{l}<0$ for the International Court). Types are not permanent but redrawn probabilistically at the beginning of each period. The International Court is of hawkish type with probability $p$ and doveish with probability $(1-p)$, while the Domestic Court is hawkish with probability $q$ and doveish with probability $(1-q)$. Variations in type can be interpreted as reflecting variations in the intensity of judicial preferences across policy areas or as resulting from changes in judicial personnel. Types remain private knowledge for the duration of the stage game. Each court knows its own type but knows only the prior probability of the other court's type being one type or the other. At the end of every period, however, types are disclosed and each court can observe whether the other court was of hawkish or doveish type 19 Future payoffs are discounted by discount factor $\delta(0<\delta<1)$. Similar to Sartori (2002), I model communication by the Domestic Court as cheap talk. That is, threatening is a costless signal that does not directly affects the payoffs.20 This permits us to investigate the conditions under which a domestic high court judges possess incentives to communicate their true preferences.

In the next two sections I discuss possible equilibria derived from this model.

\footnotetext{
${ }^{19}$ This, of course, is a simplification. After an interaction, real-world courts will usually learn something, but not everything about each others' true preferences.

${ }^{20} \mathrm{As}$ the real-world cost associated with writing obiter dicta is close to zero, it is more realistic to model it as cheap talk. In the international relations literature communication is usually treated as costly signal (Fearon, 1994, Putnam, 1988). However, it has been demonstrated that communication can be consequential, as part of a reputation-building strategy, even when modelled as cheap talk (Sartori, 2002).
} 


\section{Interplay Between International and Do- mestic Judicial Superpowers in Advanced Regimes: Coexistence Equilibrium}

As is the case for any infinitely repeated game, there are many conceptually possible equilibria in our model. Yet not all conceptually possible equilibria are empirically plausible. Using Perfect Bayesian Equilibrium as solution concept, I derive the following Pacific Coexistence Equilibrium:

Equilibrium Path: On the equilibrium path, when $0<p<1$ and $0<q<$ 1 , the two courts basically accommodate each other's existence by trading issues in a mutually beneficial way as the Domestic Court effectively uses non-compliance threats to signal its true type. When the two courts are of distinct types, the court that cares more about the issue, i.e. the hawkish type, gets its way, receiving the high jurisdictional gain, while the other court, the doveish type, acquiesces, thereby incurring the small loss jurisdictional loss ( $-J^{l}$ for the acquiescing Domestic Court, and $-\alpha^{l}$ for the acquiescing International Court). Meanwhile, when the courts are of the same type, each court alternatively gets its way. More systematically:

Strategy for International Court:

a. If type $=$ dove. In period $t=1$, it plays $M$ if Domestic Court plays $\sim T$; it plays $\sim M$ otherwise. In period $t>1$, it plays $\sim M$ if Domestic Court plays $T$, or if Domestic Court plays $\sim T$ and the last time the two courts were of doveish type the International Court played $M$. If last time the two courts were of doveish type the International Court played $\sim M$, it plays $M$.

b. If type $=$ hawk. In period $t=1$, it always plays $M$. In period $t>1$, it plays $M$ if $\sim T$, or if the last time the two courts were of hawkish type International Court played $\sim M$; otherwise it plays $\sim M$.

Strategy for Domestic Court:

a. If type $=$ dove. In period $t=1$, it plays $\sim T$ and if International Court plays $M$ it plays $\sim D$. If period $t>1$, it plays $\sim T$ and $\sim D$ when International Court plays $M$. 
b. If type $=$ hawk. In period $t=1$, it plays $T$ and plays $\sim M$ if International Court plays $M$. If period $t>1$, it plays $T$ and plays $\sim D$ when International Court plays $M$.

On the equilibrium path of play, constitutional crises, outcomes 3 and 4 in Figure 3, never occur; and only outcomes 1,2,4 and 5 are observed. Because it is common knowledge that the Domestic Court expects to profit from issuetrading, the Domestic Court has an incentive to signal its true type and the International Court to believe it. Upon receiving the Domestic Court's signal, the International Court updates its prior belief $q$ about the Domestic Court's being of type $=h a w k{ }^{21}$ So, if we denote the International Court's posterior belief about the Domestic Court being of type $=$ hawk as $\hat{q}$, then, after observing the signal $T, \hat{q}=1$. In short, as both courts expect to benefit from trading issues, judicial dialogue effectively functions as a mechanism to disclose judicial preferences and facilitate cooperation.

Punishment Path: When a court is caught deviating from the equilibrium path this triggers punishment by the other court in all subsequent periods ${ }^{22}$

a. If the court caught deviating is International Court, International Court always plays $\sim M$ while Domestic Court always plays $T$, and plays $D$ in case International Court plays $M$.

b. If the court caught deviating is Domestic Court, International Court always plays $M$, whereas Domestic Court plays $T$ with probability $q$, $\sim T$ with probability $(1-q)$ and responds to $M$ by choosing $\sim D$.

Punishment means the punished court always acquiesces, suffering jurisdictional loss, large or small, depending on its type. The punishing court, meanwhile, accrues the jurisdictional gain associated with jurisdictional expansion or reassertion corresponding to its type. When the court caught deviating is the Domestic Court because it has lied about its type-by issuing a non-compliance threat despite low-intensity preference $\left(J^{l}\right)$ for the issue at stake-shift to the punishment path means judicial dialogue breaks down. The International Court no longer heeds to the Domestic Court's message.

\footnotetext{
${ }^{21}$ It does so according to Bayes' Rule.

${ }^{22}$ The equilibrium can also be shown to exist, albeit for a smaller range of parameter values, when allowing for forgiveness after a certain number of periods. The Grim Trigger variant I use here is for ease of exposition.
} 
The threat issued by the Domestic Court, therefore, has no impact, direct or indirect, on the outcome of the game.

Equilibrium Conditions: Proof of the equilibrium is provided in the Appendix. Here I only briefly consider the conditions that must obtain in order for the equilibrium to be sustainable. Generally speaking, the equilibrium presupposes that the two courts do benefit from trading issues. This requires that both courts prefer a single-period jurisdictional loss over a constitutional crisis. ${ }^{23}$ Another condition is that types are not completely asymmetric in their probability, which rules out simultaneously having $p=1$ and $q=0$ or $p=0$ and $q=1 .{ }^{24}$ Plotted in Figure 4 are the values of $p$ and $q$ for which the equilibrium exists when holding the other parameters constant at plausible values.

\section{Figure 4 about here}

A further condition is that the two courts care at least a middling amount about the future. This requires that the expected payoff from cooperating now and in the future (the continuation value of the equilibrium path) is greater than the expected payoff from defecting now and facing the consequences in the future (the continuation value of the punishment path for the defecting court). For the Domestic Court, the strongest temptation to defect is when it is doveish and must decide whether to issue a non-compliance threat. Since the hawkish type gets its way when the other court is type $=$ dove, or when the other court is type $=$ hawk but got its way last time the courts were both hawkish, the Domestic Court may be tempted to lie and issue a threat, so as to receive payoff $J^{l}$ instead of incurring loss $-J^{l}$. The doveish Domestic Court, though, must weigh this and future losses associated with a reputation for bluff, on the one side, against the cost of sticking

\footnotetext{
${ }^{23}$ This requires that $-J^{l}>-J^{h}>\frac{J^{h}-C}{2}>\frac{J^{l}-C}{2}$ for the Domestic Court, and $-\alpha_{l}>-\alpha_{h}>\frac{\alpha-\beta}{2}$ for the International Court.

${ }^{24}$ Provided other equilibrium conditions are met, when $p=1$ and $q=0$, the equilibrium breaks down as the Domestic Court becomes indifferent between cooperation and deviation. The opposite asymmetry, $p=0$ and $q=1$, results in what amounts to a Domestic Supremacy Equilibrium. (The Domestic Court can, under this hypothesis, effectively use its signal to impose permanent acquiescence on an International Court otherwise indifferent between cooperation and defection.) These scenarios seem empirically implausible, however. In practice, judicial preferences on the same court are likely to vary in intensity across policy areas.
} 
to the equilibrium in the present in the expectation that it will be able to reap the dividends of a reputation for honesty in the future, on the other.

Punishment by the Domestic Court when the International Court is caught deviating is subject to another important incentive compatibility constraint. This is because domestic punishment cannot be credible unless the Domestic Court is willing to trigger a constitutional crisis when the defecting International Court persists in its activist stance. Were the Domestic Court unwilling to make this move, then the whole equilibrium would unravel. As a result, the International would not only accrue the full value of the jurisdictional good in the current period, but it would also conclude that it is safe always to play $M$ in the future. So in order to maintain domestic judicial deterrence, the Domestic Court must be ready to play $D$, whenever the International Court has been caught deviating in the previous period or in the current period (when playing $M$ out of turn after observing the domestic signal $T$ ). The credibility of domestic judicial deterrence requires that the expected payoff from enforcing punishment in the future, minus the cost of a constitutional crisis in the present, outweighs the payoff of domestic acquiescence now and in the future. Figure 5 illustrates how changes in the parameters of interest affect the credibility of domestic deterrence when other parameters are held constant. Panel A shows how the Domestic Court's willingness to disapply an EU act relates to the cost associated with a constitutional crisis and the rate at which it discounts future payoffs. Ceteris paribus, effective deterrence requires that for crisis costs of larger magnitude the Domestic Court care more about the future. Panel B plots the Domestic Court's high jurisdictional gain against the probability that it will be of type $=$ hawk in the future. Willingness to trigger punishment depends on high probability the Domestic Court will be of type = hawk in the future and/or that its hawkish type associates a jurisdictional gain with a higher reward. Panel $\mathrm{C}$ shows how the probability of being hawkish relates to crisis cost.

\section{Figure 5 about here}

Consistent with this analysis, experiments have shown that iterated games attaching large costs to simultaneous defection, such as the Iterated HawkDove Game, result in high levels of human cooperation (Kümmerli et al. 2007). More specifically, though, the equilibrium provides a plausible account of how the GFCC's relationship with the ECJ has evolved over time. As discussed above, both courts seem to be aware of the baneful repercussions that a constitutional crisis would bring about. The two courts also 
know that mutual accommodation represents a better alternative 25 It is also thought that "judicial dialogue" is the channel through which the two courts have achieved such mutual accommodation (Stone Sweet, 2004, Arnull, 2012). Many scholars believe that the threat issued by the GFCC in its Solange decision spurred the ECJ to subject EU legislation to more systematic human rights review (Stone Sweet, 2004, Weiler and Haltern, 1996, 460). In similar fashion, its Maastricht ruling, by asserting that ultra vires EU acts would be inapplicable in Germany, is thought to have put pressure on the ECJ to exercise more restraint in the 1990s (Dehousse, 1998) ${ }^{26}$ What legal scholars find more disconcerting is that the GFCC has alternated threats with integration-friendly rulings. For that reason, some dismiss the case law of the German Court as incoherent (Stein, 2011, Schmid, 2001). Viewed from the perspective of our issue-trading equilibrium, however, the observed oscillation in the domestic signal makes sense. Non-compliance threats and more friendly dicta are the means through which the German Court communicates the level of importance it attaches to the issue at hand. Another claim on which the model casts doubt is that a court like the GFCC need to carry its threats to execution in order for them to be effective. Because the GFCC has never disapplied an EU act, some legal scholars dismiss it as a "dog that barks but never bites" (Weiler, 2009, Schmid, 2001). Yet the model suggests that, as long as the threat of defiance remains credible, the German Court can contain the expansion of EU law without precipitating a constitutional crisis.

\footnotetext{
${ }^{25}$ While parallels with Cold War relations have been made in scholarly writings (Weiler and Haltern, 1996), a prominent GFCC judge, Udo di Fabio, has explicitly used the expression "pacific coexistence" (friedliche Koexistenz in German) to characterise the sort of relationship the German Court wants to establish with the European Court (see Fabio, 2010).

${ }^{20}$ Another illustration of successful containment by domestic judges is offered by the UK Supreme Court in its dispute with the European Court of Human Rights over the status of hearsay evidence in criminal proceedings. In its first chamber judgement, Al-Khawaja and Tahery $v$ United Kingdom, the Strasbourg Court held that criminal conviction could not be solely or decisively based on hearsay evidence. In $R v$ Horncastle, however, the UK Supreme Court explicitly declined to follow this holding. The Grand Chamber of the European Court of Human Rights, though, averted further escalation by overruling the chamber decision, yielding in effect to the position of the British Court. (I am thankful to an anonymous reviewer for pointing me this example.)
} 


\section{Weaker Domestic Courts and the Limits of Doctrinal Borrowing: International Law Expansion Equilibrium}

The analysis in the previous section demonstrates that a powerful domestic court able to inflict severe institutional damage on the international regime and its adjudicators can influence the regime's development and pace of integration, all without triggering a constitutional crisis. But what about weaker national courts in similarly advanced regimes?

As mentioned in the introduction, several domestic courts in the EU have tried to import the German ultra vires doctrine. But, as our discussion of the baseline game demonstrated, the problem for weaker domestic courts is one of power asymmetry. They may well try to mimic the doctrinal signal of stronger judicial actors, but unable to back their threats with credible deterrence, they find themselves unable to extract significant concessions from international judges. The following Perfect Bayesian Equilibrium captures the situation where the Domestic Court prefers acquiescence to a constitutional crisis while the opposite holds for the International Court:

Strategy for International Court: always plays $M$.

Strategy for Domestic Court: If type $=$ hawk, plays $T$; if type $=$ dove plays $\sim T$. Always plays $\sim D$.

In this international law expansion equilibrium, the Domestic Court fails to contain the International Court's activism. In equilibrium, only outcome 2 and 5 in Figure 3 are observed. Because the International Court knows that the Domestic Court will harm itself by following up on its threat, it ignores the domestic signal. Judicial dialogue thus has no bite. As far as the EU legal order is concerned, this implies that national courts lacking superpower status are unlikely to reinforce their bargaining position vis-à-vis the ECJ by borrowing the German ultra vires doctrine ${ }^{27}$ Faced with a non-compliance threat from a weak domestic court, the ECJ may be willing to make marginal concessions but not to compromise the core content of its doctrines.

\footnotetext{
${ }^{27} \mathrm{~A}$ weak domestic court, however, may use defiant language as a means to signal to a strong national court in the hope of encouraging to join the cause. Exploring the conditions under which this sort of horizontal dialogue can actually be consequential may be an interesting avenue for future research on inter-court dynamics in heterarchical systems.
} 
The behaviour of some domestic high courts suggest they have realised that they cannot emulate the GFCC but that, since they cannot beat the European judges, they might as well join them. Constitutional courts in Belgium, Italy, Spain and France once resisted the idea of legal integration and refused to pass on cases to the ECJ. In the meantime, though, these courts have shed the rhetoric of defiance and are now making active use of the preliminary ruling mechanism (Dyevre, 2013).

Even as a (one-off) departure from the long-term equilibrium outcome, the Czech case discussed above provides an instructive illustration of the institutional limits of doctrinal borrowing. The Czech Constitutional Court was an early adopter of the German doctrine. But its invocation did not suffice to deter the ECJ. Nor did the Czech constitutional judges inflict much harm on the ECJ when they followed through on their threat. As alluded to above, domestic factors may have played the decisive part in the Czech case. But, from the standpoint of EU law, the Czech ultra vires decision is unlikely to inspire constitutional judges in other member states (Bobek, 2014).

\section{Conclusion: The Conditions for Judicial Defiance in Non-Hierarchical Court Sys- tems}

I have tried to identify the conditions under which domestic high courts will resist the authority of international legal regimes. I have shown that, beyond the desire of judges to expand or, at least to maintain, their jurisdiction, differences in the costs courts associate with non-compliance can account for varying patterns of inter-court interaction. Domestic courts are most likely to defy international adjudicators when domestic non-compliance costs are low. Yet the model predicts that low domestic non-compliance will not systematically result in judicial defiance being actually observed, as weaker international judges have an incentive to exert restraint in anticipation of defiance. In that sense the analysis shows that the relationship between regime strength and observed domestic judicial defiance is not monotonic. One is more likely to observe overt defiance at intermediate levels of integration (contentious equilibrium) than at either low (ineffectiveness equilibrium) or high levels (supremacy equilibrium). As for the most integrated legal regimes like the EU, the model demonstrates that defiance makes domestic courts worse off, 
while the magnitude of the costs associated with a compliance crisis gives powerful judicial bodies, such as the ECJ and the GFCC, strong incentives to seek mutual accommodation through judicial dialogue. Contrary to scholars who dismiss non-compliance threats as cheap talk, I have argued that such threats can be effective, even if never actually carried to execution, as long as they are backed by credible domestic deterrence. Disparities in institutional stature and deterrence capacity then explain variations in the ability of domestic courts to extract concessions from international judges by means of dialogue. The model has many interesting implications for empirical research on the dynamics of domestic judicial compliance. I highlight three:

1. Beside documenting the dominant norm and ideology of the judiciary, researchers who aim to explain variations in the reception of international legal regimes by domestic courts should also investigate the attitudes of legislators and other governmental actors towards international law, as these determine the magnitude of domestic non-compliance costs. Scholars may want to explore, for example, how the rise of Europsceptic parties might affect commitment to EU membership and, thereby, the position of national courts; or how the revival of populism might bear on judicial support for the Inter-American Court of Human Rights in Latin America.

2. To the extent that empirical measures of judicial independence equate it with insulation from domestic politics, the model may explain the puzzling fact that countries with more independent judicial institutions often exhibit a worse compliance record with international law (Huneeus, 2013, Staton and Moore, 2011). More independent judges can afford to be less attentive to legislative preferences for international law.

3. Frequent non-compliance threats are compatible with a high degree of integration and embeddedness. While their heightened frequency may lead to a slow down in the pace of legal integration, it may not necessarily put an end to the regime's expansion. Nor is more vigorous judicial dialogue necessarily a symptom of imminent compliance breakdown. 


\section{References}

Alter, Karen J. "Explaining National Courts Acceptance of European Court Jurisprudence: A Critical Evaluation of Theories of Legal Integration." In The European Court and National Courts - Doctrine and Jurisprudence, edited by Anne-Marie Slaughter, Alec Stone Sweet, and J.H.H. Weiler, 1998, 232.

- Establishing the supremacy of European law: The making of an international rule of law in Europe. Oxford University Press Oxford, 2001.

Alter, Karen J. "The global spread of European style international courts." West European Politics 35, 1: (2012) 135-154.

Alter, Karen J., and Laurence R. Helfer. "Nature or Nurture? Judicial Lawmaking in the European Court of Justice and the Andean Tribunal of Justice." International Organization 64, 04: (2010) 563-592.

Arnull, Anthony. "Judicial Dialogue in the European Union." In Philosophical Foundations of European Union Law, edited by Julie Dickson, and Pavlos Eleftheriadis, Oxford: Oxford University Press, 2012, 109-.

Aumann, Robert, and Adam Brandenburger. "Epistemic Conditions for Nash Equilibrium." Econometrica 63, 5: (1995) 1161.

Axelrod, Robert M. The Evolution of Cooperation. Basic Books, 1984.

Bobek, Michal. "Landtová, Holubec, and the Problem of an Uncooperative Court: Implications for the Preliminary Rulings Procedure." European Constitutional Law Review (EuConst) 10, 01: (2014) 54-89.

Cameron, Charles, Jeffrey Segal, and Donald Songer. "Strategic Auditing in a Political Hierarchy: An Informational Model of the Supreme Court's Certiorari Decisions." Am. Pol. Sci. Rev. 101-116.

Carrubba, Clifford J. "Courts and Compliance in International Regulatory Regimes." J. of Pol. 67, 3: (2005) 669-689.

Carrubba, Clifford J., and Lacey Murrah. "Legal Integration and Use of the Preliminary Ruling Process in the European Union." International Organization 59, 02: (2005) 399-418. 
Costa-Gomes, Miguel, Vincent P Crawford, and Bruno Broseta. "Cognition and behavior in normal-form games: An experimental study." Econometrica 69, 5: (2001) 1193-1235.

Dehousse, Renaud. The European Court of Justice: The Politics of Judicial Integration. Palgrave Macmillan, 1998.

Downs, George W., David M. Rocke, and Peter N. Barsoom. "Is the good news about compliance good news about cooperation?" International Organization 50, 03: (1996) 379-406.

Dyevre, Arthur. "Unifying the Field of Comparative Judicial Politics: Towards a General Theory of Judicial Behaviour." Eur. Pol. Sc. Rev. 2, 02: (2010) 297-327.

_. "European Integration and National Courts: Defending Sovereignty under Institutional Constraints?" European Constitutional Law Review (EuConst) 9, 01: (2013) 139-168.

Epstein, Lee, William M Landes, and Richard A Posner. The Behavior of Federal Judges: A Theoretical and Empirical Study of Rational Choice. Harvard University Press, 2013.

Fabio, Udo Di. "Gastbeitrag Friedliche Koexistenz." FAZ.NET .

Fearon, James D. "Domestic Political Audiences and the Escalation of International Disputes." The American Political Science Review 88, 3: (1994) 577.

Fudenberg, Drew, and Jean Tirole. Game Theory. MIT Press, 1991.

Garrett, Geoffrey, R. Daniel Kelemen, and Heiner Schulz. "The European Court of Justice, National Governments, and Legal Integration in the European Union." International Organization 52, 01: (1998) 149-176.

Golub, Jonathan. "The politics of judicial discretion: Rethinking the interaction between national courts and the Eurpean court of justice." West European Politics 19, 2: (1996) 360-385.

Grimmett, Jeanne J. "World Trade Organization (WTO) decisions and their effect in US law." Congressional Research Service . 
Hartley, Trevor C. The Foundation of European Community Law. Clarendon Press, 1988.

Herzog, Roman. "Stoppt den EuGh." Frankfurter Allgemeine Zeitung .

Huneeus, Alexandra. "Courts Resisting Courts: Lessons from the InterAmerican Court's Struggle to Enforce Human Rights." Cornell Int'l L.J. 44: (2011) 493.

. "Compliance with International Court Judgments Decisions." In The Oxford Handbook of International Adjudication, edited by Cesare Romano, Karen J. Alter, and Yuval Shany, 2013, 438-463.

Kastellec, Jonathan P. "Panel Composition and Judicial Compliance on the US Courts of Appeals." JLEO 23, 2: (2007) 421-441.

Keohane, Robert O., Andrew Moravcsik, and Anne-Marie Slaughter. "Legalized Dispute Resolution: Interstate and Transnational." International Organization 54, 03: (2000) 457-488.

Kümmerli, Rolf, Caroline Colliard, Nicolas Fiechter, Blaise Petitpierre, Flavien Russier, and Laurent Keller. "Human Cooperation in Social Dilemmas: Comparing the Snowdrift Game with the Prisoner's Dilemma." Proc. R. Soc. B. 274, 1628: (2007) 2965-2970.

Kumm, Mattias. "The Jurisprudence of Constitutional Conflict: Constitutional Supremacy in Europe Before and After the Constitutional Treaty." Eur. L. J. 173-193.

Lax, Jeffrey. "Certiorari and Compliance in the Judicial Hierarchy: Discretion, Reputation and the Rule of Four." J. Theor. Politics 15, 1: (2003) 61-86.

McCormick, Neil. Questioning Sovereignty: Law, State, and Nation in the European Commonwealth. Oxford University Press, 1999.

Nagel, Rosemarie. "Unraveling in guessing games: An experimental study." The American Economic Review 1313-1326.

Nollkaemper, André. "Conversations among courts: domestic and international adjudicators." In Handbook of International Adjudication, edited 
by Romano, Karen J. Alter, and Yuval Shany, Oxford: Oxford University Press, 2013, 524-549.

- "The Duality of Direct Effect of International Law." Eur J Int Law 25, 1: (2014) 105-125.

Poiares Maduro, Miguel. "Contrapunctual Law: Europe's Constitutional Pluralism in Action." In Sovereignty in Transition, edited by Neil Walker, 2003, 501-537.

Pollack, Mark A. "Political Science and International Adjudication." In The Oxford Handbook of International Adjudication, edited by Cesare Romano, Karen J. Alter, and Yuval Shany, 2013, 357.

Putnam, Robert. "Diplomacy and domestic politics: the logic of two-level games." Int'l Organization 42, 03: (1988) 427-460.

Sadurski, Wojciech. "'Solange, chapter 3': Constitutional Courts in Central Europe-Democracy_European Union." European Law Journal 14, 1: (2008) 1-35.

Sartori, Anne E. "The Might of the Pen: A Reputational Theory of Communication in International Disputes." Int'l Organization 56, 01: (2002) $121-149$.

Schmid, Christoph U. "All Bark no Bite: Notes on the Federal Constitutional Court's "Banana Decision"." Eur. L. J. 7: (2001) 95.

Sharkey, Catherine M. "Federal Incursions and State Defiance: Punitive Damages in the Wake of Philip Morris v. Williams." Willamette L. Rev. 46: (2009) 449.

Staton, Jeffrey K., and Will H. Moore. "Judicial Power in Domestic and International Politics." International Organization 65, 03: (2011) 553587.

Stein, Professor Dr Torsten. "Always Steering a Straight Course? The German Federal Constitutional Court and European Integration." ERA Forum 12, 1: (2011) 219-228.

Stone Sweet, Alec. The Judicial Construction of Europe. Oxford [u.a.]: Oxford University Press, 2004. 
Stone Sweet, Alec, and Thomas Brunell. "Constructing a Supranational Constitution: Dispute Resolution and Governance in the European Community." Am. Pol. Sci. Rev. 92: (1998) 63-81.

Szczerbiak, Aleks, and Paul A. Taggart, editors. Opposing Europe? Volume 2: Comparative and Theoretical Perspectives. Oxford University Press, 2008.

Taggart, Paul, and Aleks Szczerbiak, editors. Opposing Europe? The Comparative Party Politics of Euroscepticism: Volume 1: Case Studies and Country Surveys. Oxford, 2008.

Weiler, J. H. H., and Ulrich R. Haltern. "The Autonomy of the Community Legal Order-Through the Looking Glass." Harv. Int'l. L. J. 37: (1996) 411.

Weiler, Josep H. H. "The "Lisbon Urteil" and the Fast Food Culture." European Journal of International Law 20, 3: (2009) 505-509.

Westerland, Chad, Jeffrey A. Segal, Lee Epstein, Charles M. Cameron, and Scott Comparato. "Strategic Defiance and Compliance in the U.S. Courts of Appeals." American Journal of Political Science 54, 4: (2010) 891-905.

\section{Appendix}

\section{A Proof of Coexistence Equilibrium}

Proof is based on the one-stage deviation principle for infinite-horizon games (Fudenberg and Tirole, 1991, 110). It demonstrates that no player can gain by unilaterally deviating from the actions prescribed by the coexistence equilibrium in any single period $t$, for all relevant histories $h$.

1. Beginning with the Domestic Court at the last node of the stage game after the International Court played $M$, it is easy to see that, to the extent that no court has been caught deviating (denote this history as $h_{1}$ ), the Domestic Court does not gain by playing $D$ rather than $\sim D$. As long as no history of deviation exists (history $=h_{1}$ ), playing $D$ does not only precipitate a constitutional crisis but because it itself constitutes deviation from 
the equilibrium path it triggers punishment from the International Court in subsequent periods. For the Domestic Court, the present value of compliance in this situation is at a minimum:

$$
\begin{gathered}
P V_{\text {domestic }}\left(\text { compliance } h_{1}\right)=-J^{h}+\frac{\delta}{1-\delta}\left(\frac{1}{2} q p J^{h}-\frac{1}{2} q p J^{h}+q(1-p) J^{h}\right. \\
\left.-(1-q) p J^{l}+\frac{1}{2}(1-q)(1-p) J^{l}-\frac{1}{2}(1-q)(1-p) J^{l}\right)
\end{gathered}
$$

This simplifies to:

$$
P V_{\text {domestic }}\left(\text { compliance } \mid h_{1}\right)=-J^{h}+\frac{\delta}{1-\delta}\left(q(1-p) J^{h}-(1-q) p J^{l}\right)
$$

For the same history, the present value of defection is at most:

$$
P V_{\text {domestic }}\left(\text { defection } \mid h_{1}\right)=\frac{J^{h}-C}{2}+\frac{\delta}{1-\delta}\left(-q J^{h}-(1-q) J^{l}\right)
$$

Therefore, as long as $P V_{\text {domestic }}\left(\right.$ compliance $\left.\mid h_{1}\right)>P V_{\text {domestic }}\left(\right.$ defection $\left.\mid h_{1}\right)$ the Domestic Court is better off playing $\sim D$. On the other hand, if the International Court has been caught deviating either in the current period (by playing $M$ out of turn) or at the end of any previous period (denote this history as $h_{2}$ ), the Domestic Court must punish the International Court as is prescribed by the Coexistence Equilibrium. In that case, the present value of compliance for the Domestic Court is at a minimum:

$$
P V_{\text {domestic }}\left(\text { compliance } \mid h_{2}\right)=\frac{J^{l}-C}{2}+\frac{\delta}{1-\delta}\left(q J^{h}+(1-q) J^{l}\right)
$$

whereas the Domestic Court's unwillingness to punish entails that the present value of defection is at best:

$$
P V_{\text {domestic }}\left(\text { defection } \mid h_{2}\right)=-J^{l}+\frac{}{1-\delta}\left(-q J^{h}-(1-q) J^{l}\right)
$$

(unwillingness to punish means playing $M$ is always safe for the International Court). The incentive compatibility constraint, therefore, is:

$$
\frac{J^{l}-C}{2}+\frac{\delta}{1-\delta}\left(q J^{h}+(1-q) J^{l}\right)>-J^{l}+\frac{\delta}{1-\delta}\left(-q J^{h}-(1-q) J^{l}\right)
$$

2. We now consider the International Court at the penultimate node of the stage game. It is easy to see that, given history $=h_{1}$, the International Court 
has no incentive to defect when it is of type $=$ hawk and the Domestic Court signals $\sim T$; the same applies when the Domestic Court was caught deviating in a previous period; ditto, for $h_{1}$, when the International Court is of type $=$ dove, but the last time the courts were of type $=$ dove the Domestic Court had its way. Now, if there was no deviation in previous period but the last time the two courts were of type $=$ hawk the Domestic Court yielded (denote this history as $h_{1 a}$ ), and the Domestic Court signalled $T$ in the current period, the present value of compliance (which involves playing $\sim M$ in the current period) for the hawkish International Court is captured by:

$$
P V_{\text {international }}\left(\text { compliance } \mid h_{1 a}, T\right)=-\alpha^{h}+\frac{\delta}{1-\delta}\left(p(1-q) \alpha^{h}-(1-p) q \alpha^{l}\right)
$$

Because it involves making an immediate concession on an issue relatively dearer to its judges, equation (7) is when the present value of compliance is smallest for the International Court. By playing $M$ out of turn, though, the International Court immediately reveals deviation, which triggers undelayed punishment by the Domestic Court:

$$
P V_{\text {international }}\left(\text { defection } \mid h_{1 a}, T\right)=\frac{\alpha^{h}-\beta}{2}+\frac{\delta}{1-\delta}\left(-p \alpha^{h}-(1-p) \alpha^{l}\right)
$$

(Immediate punishment means the International Court incurs the cost associated with a constitutional crisis in the present period while facing the prospect of perpetual punishment in subsequent periods.) Therefore, the International Court is most tempted to deviate from the equilibrium path when it is type $=$ dove, given one of the two following situations: the Domestic Court played $T$ in the current period (thus signalling hawkishness) and the last time the two courts were of type $=$ hawk the International Court yielded (denote this history as $h_{1 b}$ ); the Domestic Court played $\sim T$ in the current period and the previous time both courts were of type = dove the International Court had its way (denote this history as $h_{1 c}$ ). The present value of compliance for the International Court in both scenarios is thus captured by:

$$
\begin{gathered}
P V_{\text {international }}\left(\text { compliance } \mid h_{1 b}, T\right)=P V_{\text {ecj }}\left(\text { compliance } \mid h_{1 c}, \sim T\right)=-\alpha^{l}+ \\
\frac{\delta}{1-\delta}\left(p(1-q) \alpha^{h}-(1-p) q \alpha^{l}\right)
\end{gathered}
$$


whereas the present value of defection is:

$$
\begin{array}{r}
P V_{\text {international }}\left(\text { defection } \mid h_{1 b}, T\right)=P V_{\text {ecj }}\left(\text { defection } \mid h_{1 c}, \sim T\right)=\alpha^{l}+ \\
\frac{\delta}{1-\delta}\left(p(1-q) \alpha^{h}-(1-p) q \alpha^{l}\right)
\end{array}
$$

Therefore, the International Court is better off complying insofar as:

$$
-\alpha^{l}+\frac{\delta}{1-\delta}\left(p(1-q) \alpha^{h}-(1-p) q \alpha^{l}\right)>\alpha^{l}+\frac{\delta}{1-\delta}\left(-p \alpha^{h}-(1-p) \alpha^{l}\right)
$$

3. Finally, we consider the Domestic Court at the communication stage. The only situation in which defection can make the Domestic Court better off is when it is type $=$ dove and the previous time both courts were type $=$ hawk it yielded while the last time the courts were both type $=$ dove the International Court yielded (denote this history as $h_{1 d}$ ) ${ }^{28}$ In that case, the present value of compliance for the Domestic Court is captured by:

$$
P V_{\text {domestic }}\left(\text { compliance } \mid h_{1 d}\right)=-J^{l}+\frac{\delta}{1-\delta}\left(q(1-p) J^{h}-(1-q) p J^{l}\right)
$$

The present value of defection for the same circumstances is:

$$
P V_{\text {domestic }}\left(\text { defection } \mid h_{1 d}\right)=J^{l}+\frac{\delta}{1-\delta}\left(-q J^{h}-(1-q) J^{l}\right)
$$

This reflects the situation where the doveish Domestic Court plays $T$ in the current period, which in turn induces the International Court to infer that its true type $=h a w k$. As a result, the International Court plays $\sim M$ and the Domestic accrues payoff $J^{l}$. However, at the end of the period, the International Court observes the Domestic Court's true type and punishment ensues. So the Domestic Court is better of telling the truth as long as:

$$
-J^{l}+\frac{\delta}{1-\delta}\left(q(1-p) J^{h}-(1-q) p J^{l}\right)>J^{l}+\frac{\delta}{1-\delta}\left(-q J^{h}-(1-q) J^{l}\right)
$$

\footnotetext{
${ }^{28}$ In other situations and inasmuch as there is no history of defection, signalling hawkishness does not change the behaviour of the International Court in the current period. Meanwhile, signalling becomes inconsequential after a court has been caught deviating.
} 


\section{B Proof of International Law Expansion Equi- librium}

Proof of the International Law Expansion Equilibrium is straightforward. At the last node of the stage game, the Domestic Court cannot improve its lot by revolting against the International Court, as this brings about a constitutional crisis in the current period without stopping the Court of Justice's activism in subsequent periods. Regardless of history, the present value of compliance for the Domestic Court is at a minimum:

$$
P V_{\text {domestic }}(\text { compliance })=-J^{h}+\frac{\delta}{1-\delta}\left(-q J^{h}-(1-q) J^{l}\right)
$$

Positing that the Domestic Court prefers a jurisdictional loss over a constitutional crisis, this implicates that it is strictly better off complying. Knowing this, the International Court has no reason to deviate from $M$ at the preceding node. The lack of credible domestic deterrence entails, in turn, that the Domestic Court's signal has no effect.

Figure 1: Jurisdictional Dispute as One-Shot Game

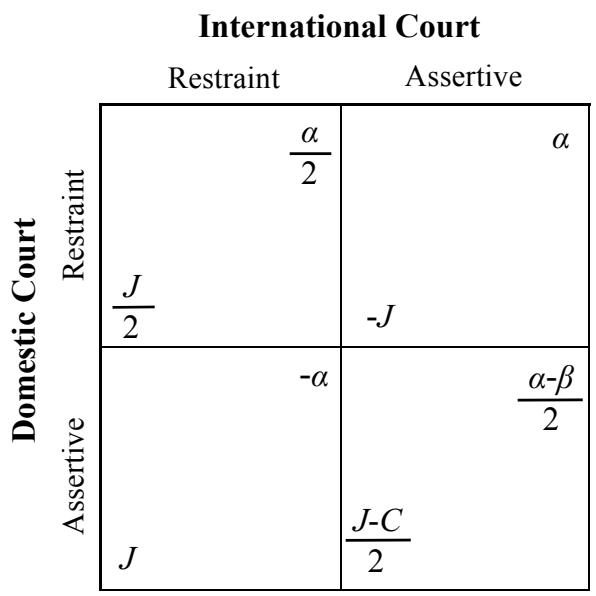

Notes: $J$ denotes the value of the jurisdictional resource at stake for the Domestic Court and $\alpha$ the value attached by the International Court to the same jurisdictional resource.

$C$ and $\beta$ represent the cost arising from a constitutional crisis for, respectively, the Domestic Court and the International Court. 
Figure 2: Mixed Strategy, Probability of Escalated Crisis

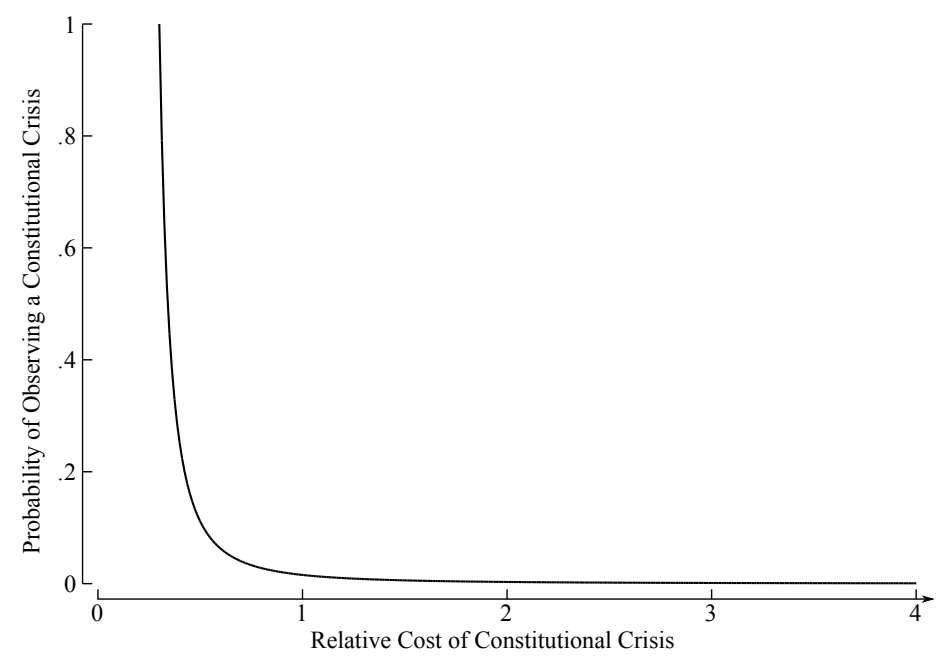

Notes: The curve represents the probability that the courts are simultaneously assertive resulting in a constitutional crisis as the cost associated with such an event rises. For this example, we assume $C=\beta$. Value of jurisdictional resource is set at $J=\alpha=.1$. 
Figure 3: Judicial Signalling, Stage Game

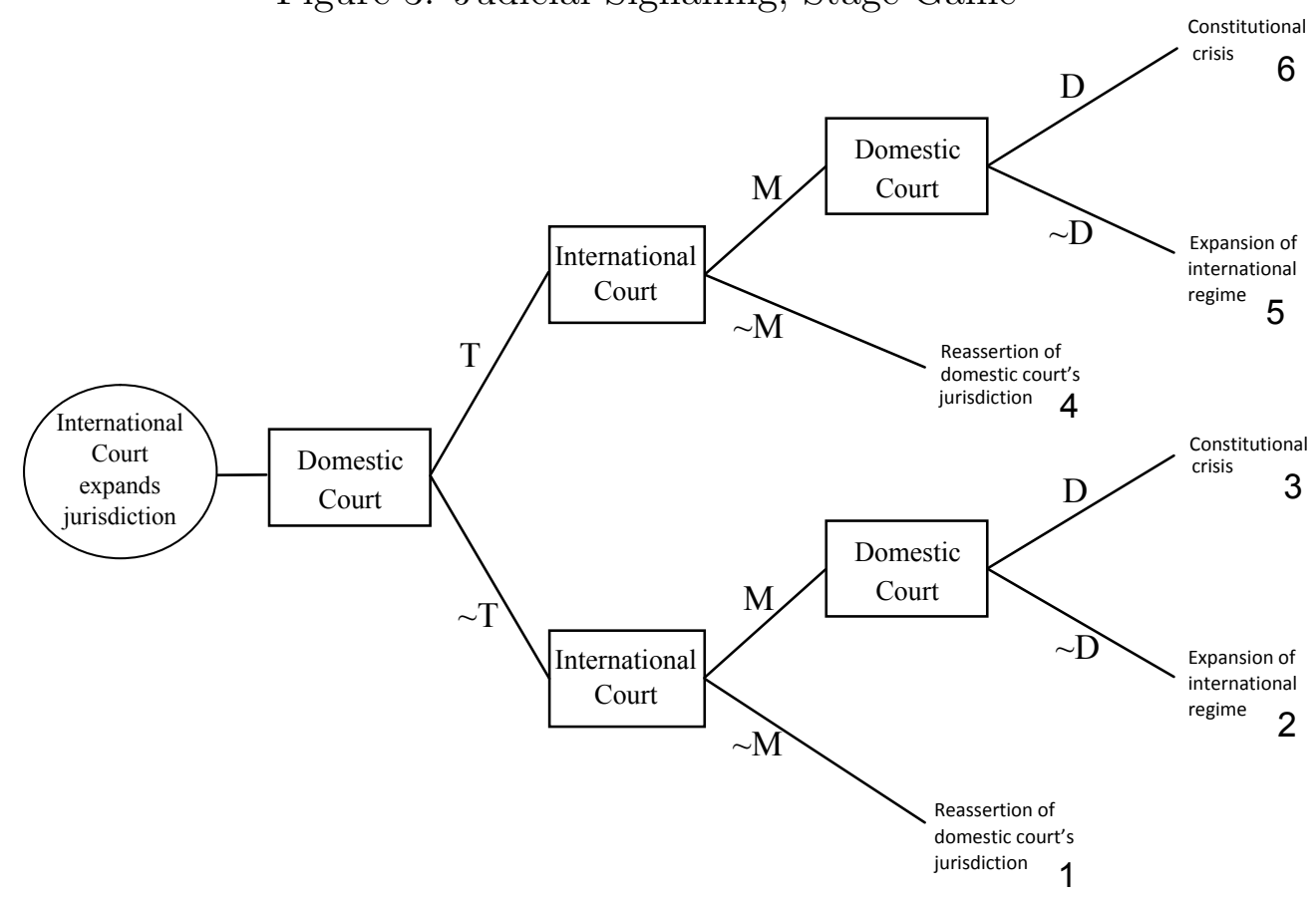

Figure 4: Type Probability and Equilibrium Behaviour

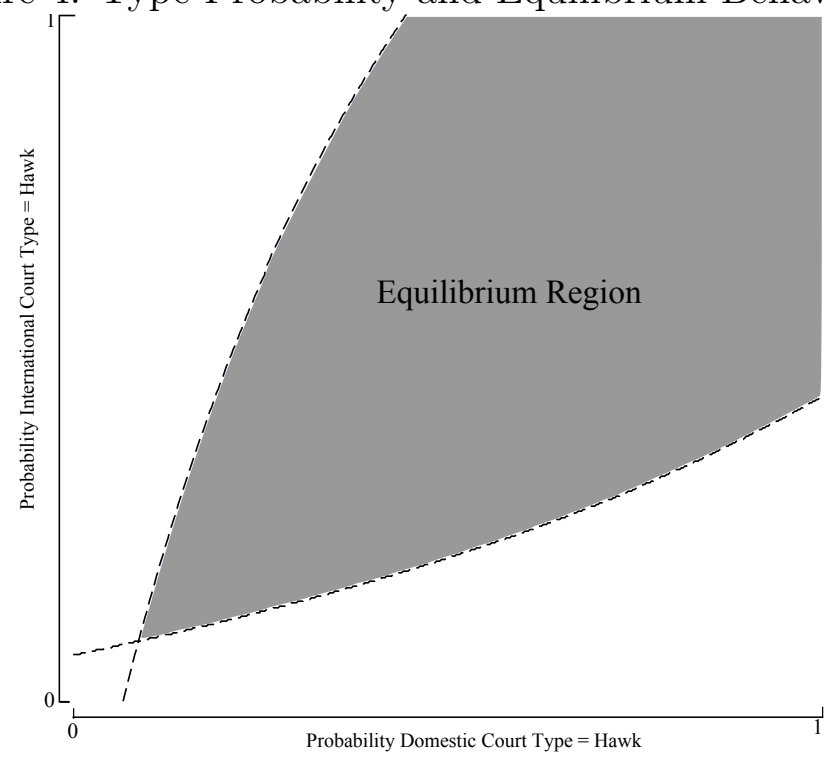

Notes: For this simulation, we set $C=\beta=10, J^{h}=\alpha^{h}=3, J^{l}=\alpha^{l}=1, \delta=0.6$. 
Figure 5: Domestic Judicial Deterrence
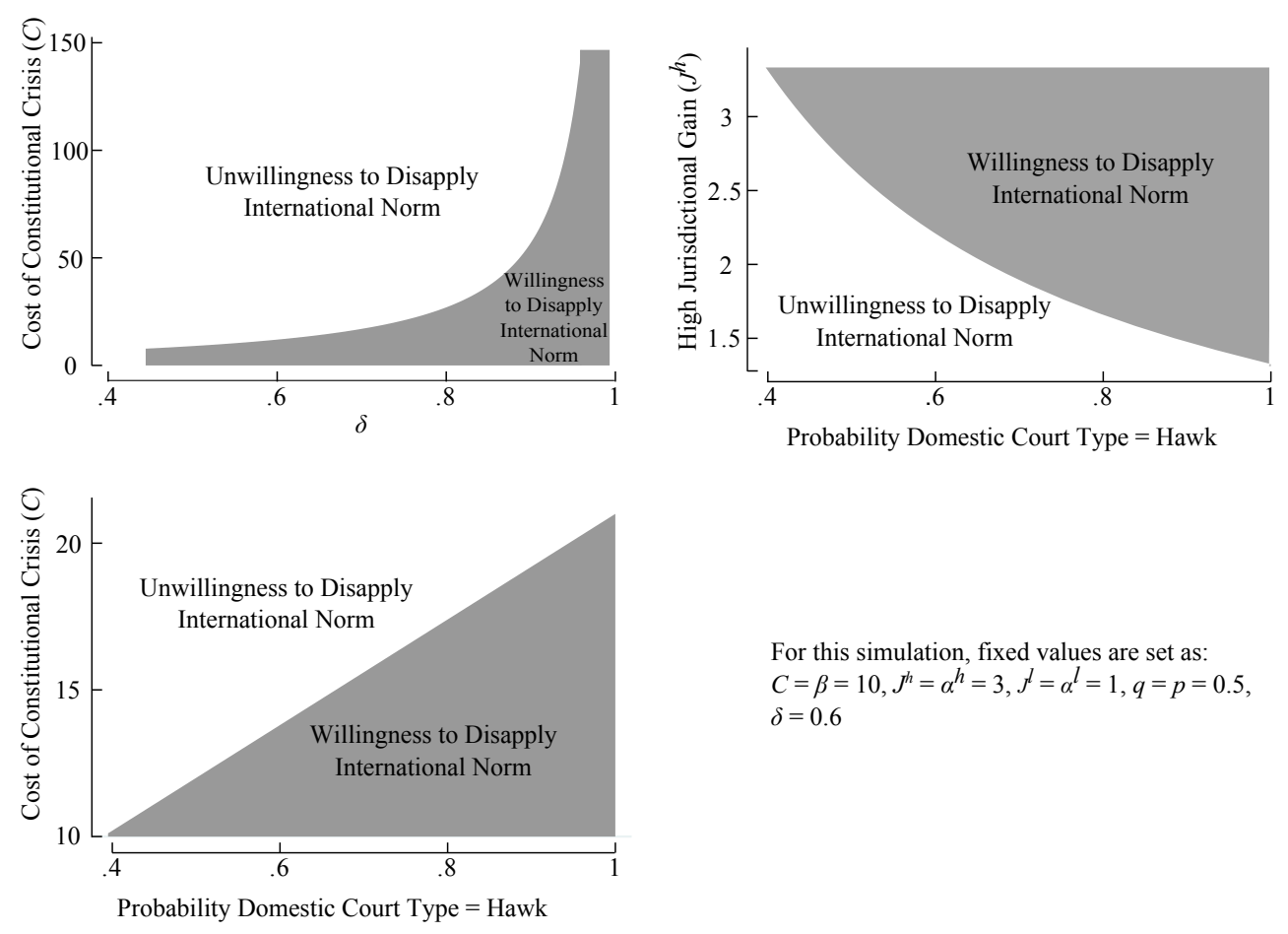

For this simulation, fixed values are set as: $C=\beta=10, J^{h}=\alpha^{h}=3, J^{l}=\alpha^{l}=1, q=p=0.5$, $\delta=0.6$ 